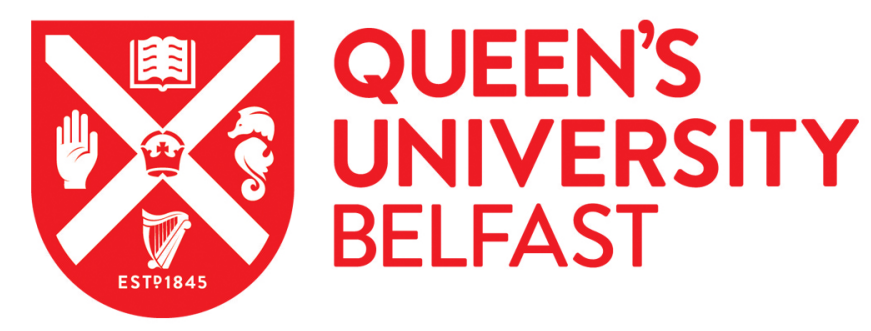

\title{
Delivery of nucleic acids for cancer gene therapy: overcoming extra- and intra-cellular barriers
}

McErlean, E. M., McCrudden, C. M., \& McCarthy, H. O. (2016). Delivery of nucleic acids for cancer gene therapy: overcoming extra- and intra-cellular barriers. Therapeutic Delivery, 7(9), 619-37.

https://doi.org/10.4155/tde-2016-0049

\section{Published in:}

Therapeutic Delivery

\section{Document Version:}

Peer reviewed version

\section{Queen's University Belfast - Research Portal:}

Link to publication record in Queen's University Belfast Research Portal

\section{Publisher rights}

Copyright 2016 Future Science

This work is made available online in accordance with the publisher's policies

\section{General rights}

Copyright for the publications made accessible via the Queen's University Belfast Research Portal is retained by the author(s) and / or other copyright owners and it is a condition of accessing these publications that users recognise and abide by the legal requirements associated with these rights.

Take down policy

The Research Portal is Queen's institutional repository that provides access to Queen's research output. Every effort has been made to ensure that content in the Research Portal does not infringe any person's rights, or applicable UK laws. If you discover content in the Research Portal that you believe breaches copyright or violates any law, please contact openaccess@qub.ac.uk. 


\section{Abstract}

The therapeutic potential of cancer gene therapy has been limited by the difficulty of delivering genetic material to target sites. Various biological and molecular barriers exist which need to be overcome before effective non-viral delivery systems can be applied successfully in oncology. Herein, various barriers are described and strategies to circumvent such obstacles are discussed, considering both the extracellular and intracellular setting. Development of multifunctional delivery systems holds much promise for the progression of gene delivery, and a growing body of evidence supports this approach involving rational design of vectors, with a unique molecular architecture. In addition, the potential application of composite gene delivery platforms is highlighted which may provide an alternative delivery strategy to traditional systemic administration.

\section{Key Words}

Cancer gene therapy,

Non-viral gene delivery,

Bio-inspired vectors,

Multifunctional gene delivery

Tumour-targeted delivery

\section{Introduction to Cancer Gene Therapy}

Cancer is a disease that arises as a result of unregulated DNA damage and mutation. Malignancies ensue when mutations in cell regulatory genes enable unopposed growth and division of cells. The aberrant nature of this growth leads to production of faulty and dysfunctional proteins which are associated with cancer progression. This genetic foundation of cancer marks it as an ideal target for genetic therapeutics. The polygenic nature of cancer results in substantial genetic heterogeneity which exists not only on a patient to patient basis, but between tumours from different locations within the same patient [1]. Consequently, approaches to cancer gene therapy can vary but the main 
strategies can be categorised into suicide gene therapy, tumour suppressor therapy, antiangiogenic therapy or cancer immunotherapy [2].

Several genes have been identified as major players in cancerous disease. The mutation of the tumour-suppressor gene p53 is implicated in many cancers and causes a loss of tumour suppressor function, thus promoting oncogenicity, and is associated with multidrug resistance and poorer prognosis [3]. Normally, p53 interacts with cellular pathways including the death-receptor pathways to suppress tumour growth [4], and the delivery of transgenes encoding p53 is a promising gene therapy strategy. The systemic administration of liposomal nanoparticles for delivery of the p53 tumour suppressor gene, known as SGT-53, for advanced solid tumours was studied in a phase I clinical trial [5]. SGT-53 was administered to patients with a range of advanced cancer types including cervical cancer, thyroid cancer and colorectal cancer. Median survival was 340 days and 7 of the 11 patients treated exhibited stable disease at 6 week assessment, with one patient reclassified from inoperable to operable due to significant tumour necrosis. This study is just one example of the potential which gene therapy holds in the treatment of cancer. As of 2016 there were over 2356 gene therapy clinical trials completed, in progress or approved worldwide, with 64\% of these studies investigating cancer diseases [6].

However, currently only three products are licenced for gene therapy. Gendicine ${ }^{\circledR}$ and Oncorine ${ }^{\circledR}$ for the treatment of head and neck cancer are licenced in China and deliver p53 tumour suppressor genes. The only product licensed in the European Union is Glybera ${ }^{\circledR}$, which can be used for the treatment of severe lipoprotein lipase deficiency [7]. The lack of licenced products is extremely disappointing considering the number of clinical trials on gene therapy, and highlights the difficulty in achieving regulatory approval. 


\section{Delivery of Genetic Material}

Gene therapy holds much promise for cancer treatment, however, a major disappointment and limiting factor in the progression of such novel therapeutics has been the lack of a comprehensive delivery vehicle. Various delivery systems are currently used in research, but to date no candidate has excelled to meet all the desired criteria for a successful gene delivery system, and generally each has major flaws and limitations.

As yet, viral vectors are the most efficient gene delivery agents. Viruses have naturally evolved the ability to transfer genetic material into target cells. For this reason, viruses have been hijacked for gene delivery purposes [8]. Unfortunately, major safety concerns regarding mutagenesis, toxicity and immunogenicity in addition to limited capacity for nucleic acid carriage reduced the appeal of using viral vectors $[9,10]$. Consequently, and the proportion of clinical trials that employ retroviral vectors has declined from $28 \%$ in 2004 to $18.7 \%$ currently [11,12].

Non-viral gene delivery utilises a wide array of delivery systems including cationic polymers, liposomes, proteins and peptides which have the ability to package nucleic acids and deliver them into cells [13]. These approaches have shown promise for gene delivery, and have the potential to circumvent the problems associated with viral vectors [14]. However the transfection efficiencies of non-viral vectors are significantly lower than those of viral vectors [15]. Moreover, the complexity of design and assembly of non-viral vectors is not to be underestimated, as the numerous obstacles that face gene therapy must be considered. Several barriers exist, both extra- and intracellular, which destroy foreign genetic material, reduce transfection and prevent the introduction of therapeutic genes into cells. Successful gene therapy relies largely on the development of an efficient vector which can overcome these barriers to deliver the genetic material to its target site [16]. The ideal non-viral delivery vector must be non-toxic, non-immunogenic and multifunctional. 
Table 1 highlights the properties of an ideal non-viral vector required to overcome various barriers to gene delivery.

Table 1: Functional elements of a gene delivery vector required to evade various barriers to gene delivery

\begin{tabular}{|c|c|c|}
\hline $\begin{array}{l}\text { Barriers to gene } \\
\text { delivery }\end{array}$ & Function required of delivery vector & Rationale \\
\hline \multirow{4}{*}{ Extracellular } & Package and condense nucleic acids & $\begin{array}{l}\text { Particles are required to be a suitable size for in } \\
\text { vivo delivery and cellular uptake, usually in the } \\
\text { nano scale [17]. }\end{array}$ \\
\hline & $\begin{array}{l}\text { Protect genetic cargo from } \\
\text { degradation }\end{array}$ & $\begin{array}{l}\text { Protection from nucleases is vital to ensure the } \\
\text { therapeutic is intact and functional when the } \\
\text { target site is reached [18]. }\end{array}$ \\
\hline & $\begin{array}{l}\text { Avoid opsonisation and clearance } \\
\text { from systemic circulation }\end{array}$ & $\begin{array}{l}\text { Opsonisation and rapid clearance by the RES } \\
\text { system results in limited genetic material } \\
\text { reaching the target site [19]. }\end{array}$ \\
\hline & Target correct cells & $\begin{array}{l}\text { Specific and exclusive transfection of cancer cells } \\
\text { will reduce off-target effects and may improve } \\
\text { efficiency of the therapeutic [20]. }\end{array}$ \\
\hline \multirow{4}{*}{ Intra-cellular } & $\begin{array}{l}\text { Stimulate internalisation to target } \\
\text { cells }\end{array}$ & $\begin{array}{l}\text { Cellular uptake may be via a range of different } \\
\text { endocytic pathways, facilitated by receptors or } \\
\text { direct penetration }[21,22] \text {. }\end{array}$ \\
\hline & Avoid/escape endosomal entrapment & $\begin{array}{l}\text { Escape from the endosome is vital to allow } \\
\text { progression to the nucleus and avoid destruction } \\
\text { of the therapeutic [23] }\end{array}$ \\
\hline & Traffic DNA towards nucleus & $\begin{array}{l}\text { Movement through the cytosol towards the } \\
\text { nucleus can be very slow and may be impeded } \\
\text { by organelles [24]. }\end{array}$ \\
\hline & Promote nuclear import of DNA & $\begin{array}{l}\text { The nuclear envelope is the final barrier and } \\
\text { active entry into the nucleus may be required for } \\
\text { transcription and gene expression to occur [25]. }\end{array}$ \\
\hline
\end{tabular}

Therefore, if gene therapy is to be truly successful, it is necessary to focus on the design of a delivery vehicle to fulfil the functional demands and satisfy the regulatory authorities. Herein, we will describe the most important barriers to nucleic acid delivery for gene therapy and discuss the various strategies that have been used or have potential to be used for delivery of genetic material for cancer gene therapy. 


\section{Extracellular Barriers}

\subsection{Mechanisms of clearance from systemic circulation}

Advanced cancerous disease are generally characterised by distant metastases that therefore dictate systemic delivery of treatment. This exposes the genetic therapy to a range of extracellular obstacles. The reticulo-endothelial system (RES), also known as the mononuclear phagocyte system (MPS) [26], poses a major threat to the journey and integrity of genetic material in the systemic circulation. Typically, clearance of gene delivery systems from the circulation occurs rapidly following systemic administration via opsonisation and phagocytosis [27]. Initial opsonisation marks undesirable material in circulation for phagocytosis, where macrophages engulf and either destroy or remove it from circulation [19]. Figure 1 demonstrates some of the extracellular barriers to gene delivery which exist following systemic delivery.

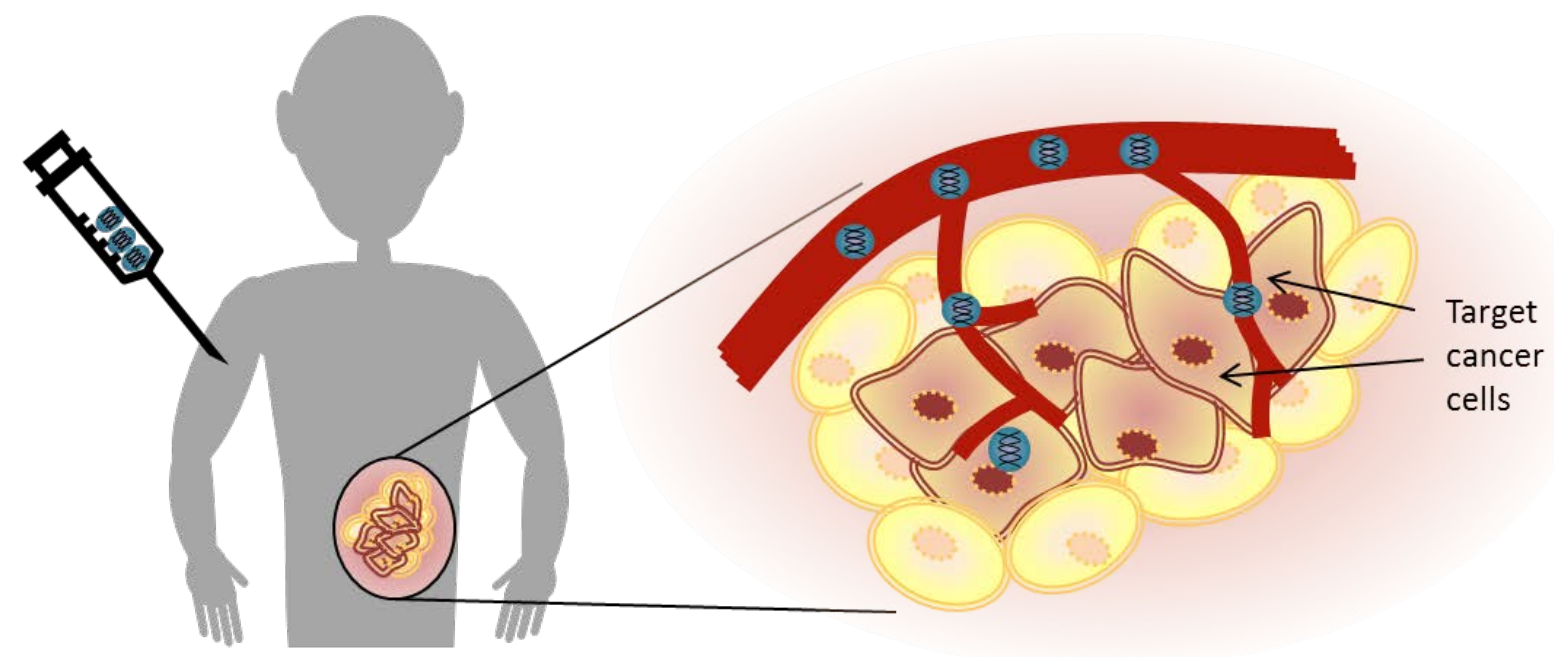

Figure 1. Non-viral gene delivery vectors, delivered systemically, travel in the blood circulation to target malignant cells. Vectors must survive clearance from the reticuloendothelial system (RES) and extravasate from poorly structured blood vessels in the tumour, before endocytosis into tumour cells can occur. 
Opsonisation is initiated by adsorption of plasma proteins in the blood stream to the surface of the foreign material. Up to 30 soluble plasma- and cell surface-bound proteins are known to be involved in this process, with complement components $\mathrm{C} 3, \mathrm{C4}$, and C5 commonly involved [28]. A cascade of events is triggered where complement proteins covalently bind to the foreign material, tagging it for destruction by phagocytes which possess complement receptors (mainly CR1 or CD35) $[29,30]$.

Phagocytosis and destruction of foreign material is then carried out by macrophages in the lungs and spleen, as well as Kupffer cells in the liver [27]. Kupffer cells are the resident macrophages in the liver which exist within the lumen of hepatic blood vessel walls, and play a central role in systemic defence [31]. Various destructive enzymes and chemical factors within macrophages degrade the unwanted material. In the case of non-biodegradable polymers however, this process has no significant effect, and fate of the polymer depends upon relative size and molecular weight. Particles larger than the renal threshold (usually $>200 \mathrm{~nm}$ in size or $>5000 \mathrm{Da} \mathrm{MW}$ ) will be sequestered in an MPS organ (liver, lungs or spleen) [19]. Thus, biodegradability and a low molecular weight should be desirable criteria in the design of a delivery vector for systemic delivery of gene therapy, since the build-up of non-biodegradable materials in MPS organs could cause toxicity.

\subsubsection{Strategies to avoid clearance following systemic circulation}

Avoidance of the initial opsonisation process is critical if particles are to remain in circulation and circumvent clearance. The main parameters to consider for vector design here are particle size, surface charge and hydrophobicity. Particles above the renal threshold (>200 nm) and those with a cationic nature attract interaction with anionic blood proteins. Hydrophobicity also enhances the binding of complement proteins during the opsonisation process triggering sequestration by macrophages and clearance from circulation [18,32].

Stealth molecules have been extensively used as a means of avoiding clearance and increasing circulation time of delivery systems administered parenterally. They are usually long hydrophilic 
polymer chains which are flexible and have a neutral charge. They function to shield the delivery system from opsonins by reducing the electrostatic and hydrophobic interactions that trigger opsonisation, and also increase stability [19]. Increased stability of particles results in reduced aggregation as well as a decrease in off-target effects. The most widely studied stealth molecule is polyethylene glycol (PEG). PEG is extremely effective and has been added to various cationic delivery systems, increasing circulation times successfully. It also has regulatory approval due to its lack of toxicity or immunogenicity which makes it an extremely attractive component in the design of gene delivery systems [33]. Other polymeric compounds that have been used in the preparation of gene therapy nanoparticles include copolymers of lactic and glycolic acids, which have excellent biocompatibility, biodegradability and mechanical strength, and amphiphilic block copolymers, such as poly(lactide)-methoxy polyethylene glycol (PLA-mPEG), poly(lactide-co- glycolide) (PLGA)-mPEG, PLA-PEG-PLA and PLA-Tween 80, which have been shown to provide more effective performance for drug delivery both in vitro and in vivo than PEG alone [34]. Tactical engineering of PEGylated systems by adjusting surface coverage and use of different PEG molecular weights, chain densities and conformations can produce a vehicle with characteristics suitable for avoidance of opsonins [19]. Figure 2 exhibits the process of opsonisation and phagocytosis of a cationic delivery system and the use of PEGylation to avoid this. 

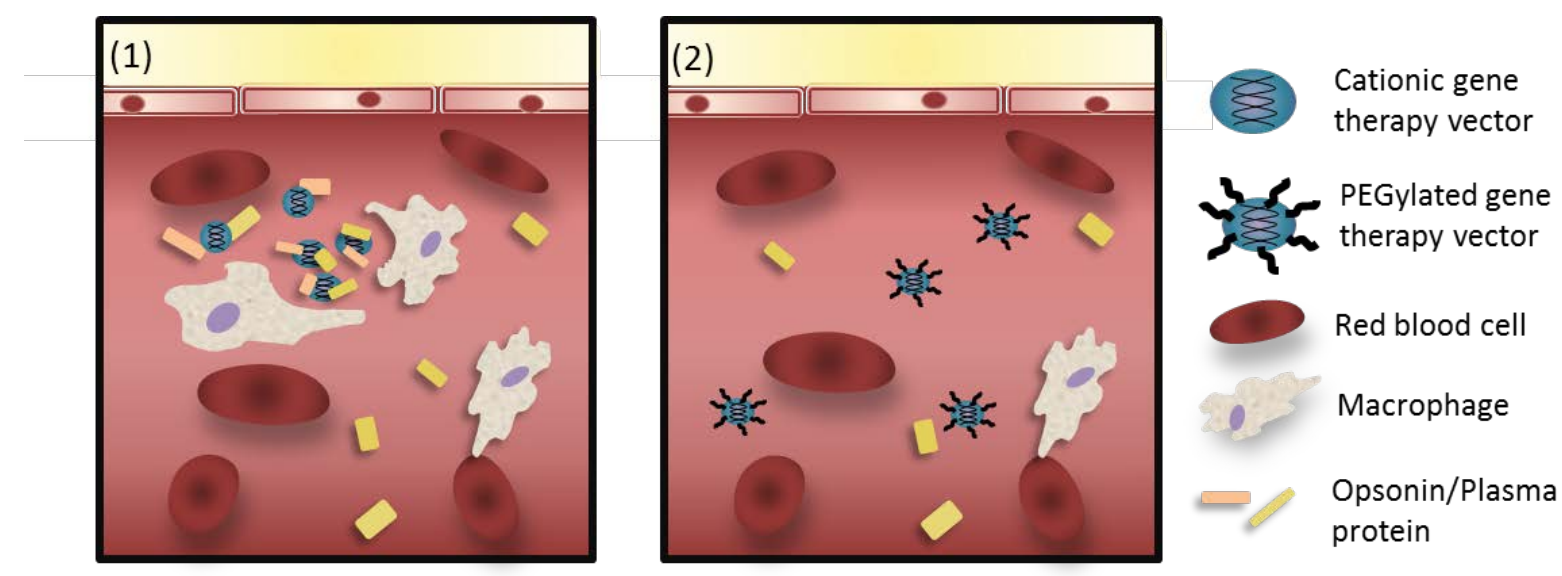

Figure 2. (1) Opsonins (e.g. complement protein C3) rapidly bind to cationic gene delivery vectors and trigger phagocytosis by macrophages. As a result, the vectors are rapidly cleared from circulation and are unlikely to reach the target tumour. (2) Opsonisation and subsequent clearance is reduced with the addition of polyethylene glycol (PEG). The hydrophilic polymer forms a corona around the particles which reduces the binding of opsonin proteins and increases the circulation time of the vector, allowing it to reach the desired site.

\subsection{Tumour microenvironment}

The tumour microenvironment is characterised by a chaotic, leaky vasculature and interstitial hypertension, which leads to acidic and hypoxic conditions. A range of extracellular proteases are produced which are known to degrade the extracellular matrix allowing for invasion and tumour progression. Together, these factors hinder drug distribution and reduce the therapeutic efficacy of nanoparticles as delivery to the target site is impeded [36].

\subsubsection{Exploiting the tumour microenvironment for drug delivery}

\subsubsection{Leaky vasculature}

The ability of tumours to trigger angiogenesis for increased tumour blood supply is associated with more aggressive tumours, metastasis and poor prognosis. However, the rapid growth and mutation leads to a poorly structured and disordered vasculature that is functionally flawed. Normally, endothelial cells line the walls of blood vessels serving as a barrier between the blood circulation and 
surrounding tissues. In the tumour microenvironment, however, endothelial cells are disorganised and irregularly shaped, causing abnormal vessel structure with loose interconnections resulting in leakiness [37]. This leakiness may be exploited for passive tumour targeting; a delivery system engineered to have a prolonged circulation time can extravasate from the blood stream preferentially at these leaky sites, resulting in retention and accumulation in the tumour site. Preferential release at tumour sites may be mediated by the enhanced permeability and retention (EPR) effect [33]. The EPR effect has been well documented and successfully exploited by various delivery systems. Many studies in animals have shown passive tumour accumulation of therapeutics, however this has not fully translated to studies in humans [35]. The literature can be contradictory on this topic with many opinions divided on the EPR effect. In addition, the heterogeneity which exists in tumour biology may affect the distribution and penetration of passive therapeutics, resulting in inconsistent, inadequate or restricted therapeutic effects [38]. Considering these shortcomings, total reliance on a passive targeting strategy of this nature may not be sufficient or reliable for cancer gene therapy. It is clear that a deeper knowledge of the tumour microenvironment is necessary to develop more active targeting strategies for efficient, reliable intra-tumoural delivery of gene therapeutics.

Although PEGylation can improve the pharmacokinetic profile and biodistribution of therapeutics, it can limit cellular penetration once the target site is reached. This phenomenon, termed the PEG dilemma, can hinder gene expression by obstructing entry of delivery systems into tumour cells [39], probably due to the impact of PEG on particle size and particle-cell electrostatic interactions. To circumvent this, delivery systems that comprise detachable or cleavable PEG have been developed, whereby the PEG corona is shed once the vector has reached its target site. These 'smart' delivery systems can exploit conditions in the tumour environment such as $\mathrm{pH}$ and enzymatic activity to release the therapeutic. This also doubles as a targeting strategy, as release of the sheddable PEG should only be triggered in the tumour environment $[40,41]$. 


\subsubsection{Hypoxia and acidity}

An erratic and inadequate vasculature coupled with rapid growth results in areas within a tumour which are poorly perfused and hypoxic. Anaerobic glycolysis occurs in areas of hypoxia producing acidic metabolites such as lactic acid. This results in an acidic extracellular $\mathrm{pH}$ that ranges from 5.7 to 7.0 , which is more acidic than blood $(\mathrm{pH} 7.4)[42,43]$. The results of this defective respiration and metabolic disturbance are extremely important for tumourigenesis and are associated with treatment resistance and poor prognosis [44]. However, these conditions have also been exploited by smart delivery systems.

Acid-sensitive linkages such as ester and hydrazine bonds have been used to conjugate PEG to delivery vectors. Once in the acidic tumour environment, the PEG chain is cleaved, exposing the cationic particle to cell membranes and initiating internalisation. Fella et al reported a 14-fold increase in transgene expression in HUH7 hepatocellular carcinoma tumours via a targeted polyplex system with PEG attached via an acid-labile hydrazone linkage when compared to the non-acidsensitive formulation following systemic administration [45]. $\mathrm{pH}$ sensitive block copolymers hold promise in the design of a vector which takes advantage of the tumour microenvironment. Li et al describe a pH-sensitive polymer, poly(L-histidine)-poly(lactide-co-glycolide)-tocopheryl polyethylene glycol succinate (PLH-PLGA-TPGS) for the delivery of Doxorubicin (DOX) for cancer chemotherapy. Functionalization with the $\mathrm{pH}$-responsive polymer achieved 4.55 -fold more cytotoxicity in MCF-7 breast cancer cells [34]. The $\mathrm{pH}$ responsive nature is due to the PLH component that has an unsaturated imidazole ring and becomes protonated in the acidic environment of the tumour causing the polymer to swell and release the drug within. Although this study does not describe the delivery of gene therapeutics, it is a good example of how a delivery system can be engineered for tumour targeting purposes and could potentially be modified for gene delivery applications. 


\subsubsection{Cancer-associated proteases}

Cancer-associated proteases (CAPs) are proteases that are often up-regulated in and characteristic of malignancies. Usually absent in healthy tissues, the CAPs include urokinase plasminogen activator (UPA), the matrix metalloproteases (MMPs), and cathepsins [46]. The presence of CAPs has been associated with aggressive disease and poor prognosis due to their involvement in invasion and the formation of metastatic lesions. Given their specificity for the tumour environment, vectors have been developed that are CAP-activatable.

MMPs are a range of proteases which are commonly secreted by tumours and function in the degradation of the extracellular matrix, facilitating growth and progression of tumours [47]. In one study, the authors used an MMP-7-cleavable linker to tether PEG to polymeric nanoparticles for the delivery of anti-luciferase siRNA [48]. In vitro supplementation of MDA-MB-231 transfection medium with recombinant MMP-7 improved transfection efficiency 2.5-fold over that observed when MMP-7 was absent. A nanoplatform which incorporates a peptide cross-linker including the MMP-2 substrate sequence (GPLGVRGK) for MMP-responsive tumour delivery coupled with a tumour homing peptide (CRGDK) has been used to mediate cellular internalisation [49]. RGD peptide is a commonly used peptide targeting ligand and is involved in cell adhesion to cell surface integrins [50]. Integrin receptors such as $\alpha v \beta 3$ integrin and related $\alpha$ v-integrins, are upregulated in various aggressive cancers and RGD has been incorporated into non-viral delivery systems for targeting tumours [51,52]. In vivo tumour-targeting efficacy of CRGDK-modified nanovesicles for delivery of Cy-5 labelled irinotecan was evaluated in HT-29 colon carcinoma tumour-bearing BALB/c nude mice and monitored by near-infrared (NIR) fluorescence imaging. Fluorescence was found to be significantly higher in the tumours of mice treated with the MMP-sensitive nanovesicles at $8 \mathrm{~h}$ to 24 h post-injection compared to those treated with nanovesicles that lacked the MMP-sensitive linker. Furthermore, tumour growth delay of about $84.1 \%$ was observed when the nanovesicles were used to deliver irinotecan which was significantly more than other non-MMP sensitive treatment groups. 
This study is a good example of how more than one targeting strategy can be used together to improve tumour delivery. The RGD peptide binds to integrin receptors on tumour cells and was useful for tumour homing, while the MMP-repsonsive peptide was cleaved by CAPs, allowing activation of the nanovesicles when present at the tumour site.

\section{Intracellular Barriers}

Many promising strategies have been employed which have the potential to navigate genetic material safely through the systemic circulation towards the target tumour. However, upon arrival at the tumour, a vector is met with a host of intracellular barriers, including the cell membrane, endosomal entrapment, immobility in the crowded cytoplasm and the nuclear envelope. Figure 3 highlights the main intracellular hurdles which a vector must overcome before successful gene delivery can occur.

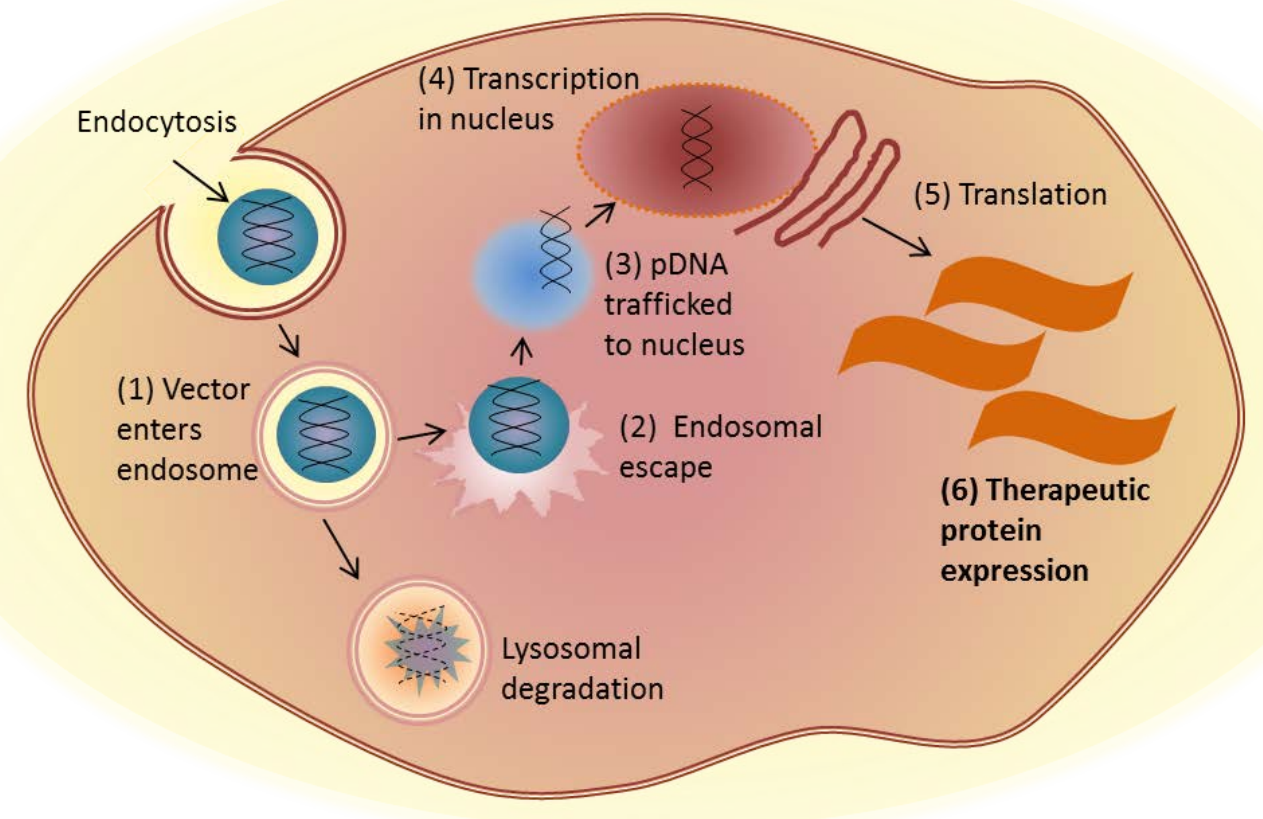

Figure 3. (1) Once endocytosis occurs, the vector enters the endosomal compartment. If escape from the endosome is not facilitated, the vector will progress into a lysosome and be degraded. (2) Following endosomal escape, the therapeutic nucleic acid must be (3) trafficked towards and enter 
the nucleus. (4) Transcription of the therapeutic DNA is followed by (5) translation and (6) expression of the therapeutic protein.

It should be noted that some nucleic acid therapies have been developed, including small interfering RNA (siRNA) and microRNA, which require delivery to the cytosol of the cell, reducing the number of barriers to be overcome. However, for conventional gene therapy, therapeutic DNA requires delivery to the nucleus for transcription and thus, each intracellular barrier must be addressed in turn before successful gene delivery can occur.

\subsection{Internalisation}

The cell membrane poses a major barrier to gene delivery since entry into cells is tightly controlled and regulated. The anionic lipophilic bilayer prohibits the entry of macromolecular anionic nucleic acids in their naked form [14]. Delivery systems for gene therapy work to condense therapeutic genetic material into a size suitable for cellular entry, usually $\leq 200 \mathrm{~nm}$ in diameter. Most DNAcondensing systems are cationic in nature and mask the anionic charge of the nucleic acid, thereby enhancing the interaction with cell membranes through electrostatic interactions [17].

Factors that impact the cellular internalisation of a nano-scale entity include the size and charge of the entity, cargo properties, as well as cell type and cell surface receptors [53,54]. Endocytosis, which can be further categorised into clathrin-mediated [55], caveolae-mediated [56], or macropinocytosis [57]), is thought to be the main uptake pathway for most gene delivery vectors.

The route of entry is important for gene delivery as it dictates the fate of the particle once internalised. This is particularly true for endocytic pathways, which usually culminate in endosomal entrapment with subsequent lysosomal destruction of the internalised vector. Some groups have proposed that another, more direct internalisation pathway (termed 'transduction') has served as a route of entry for cationic vectors, which does not involve endocytic or endosomal compartments. It 
is suggested that transduction is triggered through non-specific electrostatic interactions between the cationic vector and anionic groups present on the cell membrane [58]. However, little is known about this entry mechanism, and further research is warranted, since avoidance of the endosomal compartment is an attractive option for non-viral gene delivery. By elucidating the precise entry mechanisms, it may be possible to improve cellular uptake efficiency with intelligent vector design and thus improve gene therapy outcomes.

\subsubsection{Improving cellular uptake}

Cationic non-viral delivery systems including polymers (e.g. poly-L-lysine (PLL), poly(ethylenimine) (PEI)) and lipids (e.g., 1,2-dioleoyloxy-3-(trimethylammonio)propane (DOTAP)) have been used to package DNA forming polyplexes and lipoplexes respectively [13]. However, problems with nonbiodegradability and toxicity [59] have led to increasing attention being paid to delivery systems which are biocompatible, have low toxicity and are easily fine-tuned [60,61]. DNA nanostructures have been developed as a non-cationic delivery platform compatible with biological systems. Recent advances in this field have resulted in development of 3D DNA nanostructures, e.g. DNA hydrogels and DNA tetrahedrons, which have the ability to deliver a range of cargo including drugs and nucleic acids into cells [62]. DNA tetrahedral nanostructures functionalised with folic acid for targeting of tumour cells expressing folate receptors were used to deliver anti-luciferase siRNA to BALB/c nude mice bearing luciferase expressing KB (HeLa) tumours [63]. Following systemic delivery via tail vein injection, luciferase expression was found to be significantly reduced by about $50 \%$. However, this promising form of nanotechnology is a very recent advancement in the early stages of development, and much work is required to elucidate the exact functional mechanisms and physiochemical properties of these novel delivery systems. Peptide delivery systems have been extensively and successfully utilised for DNA delivery due to their dual function in DNA condensation and electrostatic interactions with anionic cell membranes facilitating internalisation. 
Cell penetrating peptides (CPPs) have the ability to cross the cell membrane without the need for receptors or other carriers, via various mechanisms, including endocytic pathways or through direct translocation [64]. CPPs are now well established as successful delivery vectors, and are used extensively to enhance cellular uptake of a range of cargoes to various cell types [65]. TAT peptide (GRKKRRQRRR), which is derived from HIV-1 [66] has strong cell penetrating ability, consequent of its basic amino acids, lysine and arginine and was one of the first peptides to be used to facilitate cellular uptake of various cargo. Since then, novel CPPs have been derived which have a wide range of structures and characteristics, but generally CPPs can be cationic/basic, amphipathic or hydrophobic in nature [67].

Amphipathic CPPs are usually composed of an alpha helical structure with spatial separation between hydrophobic and hydrophilic amino acids residues. This structure is essential for their interaction and passage across the cell membrane with hydrophobic portions of the peptide able to insert into the lipid membrane, triggering uptake [68]. However, in the case of Penetratin peptide (RQIKIYFQNRRMKWKK), derived from the third helix of the homeodomain of Antennapedia [69], the peptide's cationic nature was found to be responsible for cell penetration, rather than its helical structure [70]. Hence, the design of cationic CPPs with a more simple structure has gained attention, with the focus being on the inclusion of basic amino acid residues, namely arginine, lysine and histidine [71]. Particle internalisation is triggered by electrostatic interaction between the cationic CPPs and the anionic species (such as lipid head groups or proteoglycans) of the extracellular surface of the cell membrane [72]. Arginine residues have been shown to possess stronger cell-penetrating ability than lysine or histidine, owing to the guanidinium moiety in the arginine amino acid side chain, which is crucial for cell entry. As a result, arginine-rich peptides have been extensively researched, and oligoarginines have become well established CPPs [73-76]. 
Octa-arginine (R8) is the most commonly used arginine-rich CPP, and is usually added to an existing delivery system to enhance the cellular uptake. R8 was coupled to a polymeric gene vector, composed of $\beta$-cyclodextrin (b-CyD) and low-molecular-weight poly-ethylenimine ( $\mathrm{PEI}, \mathrm{MW} 600$ ) known as PC, to form nanovectors for highly efficient gene delivery to tumour cells. R8-involved complexes delivering luciferase plasmid DNA showed higher transfection efficiency in vitro in C6 rat glioma cells and A549 adenocarcinoma human alveolar basal epithelial cells than PEI $25 \mathrm{kDa}$ complexes [77]. R8 has been shown to enhance the cellular uptake of various vectors and cargoes and as a result has become one of the most widely studied CPPs.

Despite uncertainty surrounding the exact mechanism of internalisation, CPPs are very attractive agents for development of gene delivery systems [71]. CPPs do have shortcomings though, especially for in vivo applications, due to instability in systemic circulation and uncertain internalisation pathways. One method to improve the application of CPPs has been the use of unnatural or D-form amino acids which renders the peptide resistant to protease degradation, enhancing stability, however this does not address problems with opsonisation [78]. Despite this, CPPs have become well established as part of larger vector systems and often are incorporated to improve cellular uptake.

\subsection{Endosomal entrapment}

The endosomal compartment has an integral cell regulatory function. It is responsible for monitoring material entering the cell. The endosome will either recycle matter to the cell membrane or direct it to lysosomes for degradation. Hence, the endosome represents one of the major limitations to efficient gene therapy. Generally CPPs, such as TAT and oligoarginines, lack the ability to escape the endosome resulting in poor transfection efficiencies $[79,80]$. In order to avoid destruction, a gene delivery system must facilitate escape from the endosome, which can be achieved through different 
mechanisms, including increasing osmotic pressure so that the endosome bursts, or by causing leakage through pore formation in the endosomal membrane.

\subsubsection{Enhancing endosomal escape}

A number of strategies are employed by delivery systems to escape endosomal entrapment. The 'proton sponge effect' is utilised by polymers and peptides rich in histidine. Histidine residues possess imidazole side chains which become protonated in the acidic conditions causing an influx of water and buffering of the endosome resulting in swelling and bursting, releasing the endosomal contents [81,82]. H5WYG is a histidine-rich peptide, derived from the HA2 subunit of haemaglutinin (HA) protein of the influenza virus, which has improved gene delivery by facilitating endosomal escape [83]. A two-fold increase in luciferase mRNA level was detected by Asseline et al when H5WYG was added to an antisense oligonucleotide (2'-Ome RNA705) targeting aberrant splicing of luciferase pre-mRNA in HeLa pLuc705 cells [84]. The importance of the histidine residues was highlighted in a study conducted by Lo et al where the addition of 10 histidine residues to TAT increased luciferase transgene expression up to 7000-fold in the human glioma cell line U251 in vitro [85].

Membrane destabilisation is a mechanism of endosomal escape that is employed by fusogenic peptides, which occurs through interaction between the cationic amino acids and the anionic lipids in the endosomal membrane, forming pores which disrupt the membrane and cause leakage [86]. Once inside the endosome, the acidic pH triggers a conformational change in the helical structure of fusogenic peptides which leads to interaction and disruption of the phospholipid membrane of the endosome $[23,67]$. Liou et al described the functionalisation of nona-arginine (R9) with the fusogenic hemagglutinin-2 (HA2). Following tagging of the vector with red fluorescent peptide (RFP), A549 human lung carcinoma cells were found to have significantly more RFP levels in vitro when treated with the R9-HA2 peptide than those treated with R9 alone [87]. 
RALA (WEARLARALARALARHLARALARALRACEA) is a fusogenic amphipathic peptide with a cationic nature which has multifunctional activity for gene delivery [88]. RALA was rationally derived from the first cell-penetrating amphipathic peptide demonstrated to possess fusogenic activity named GALA (WEAALAEALAEALAEHLAEALAEALEALAA), and its derivative KALA (WEAKLAKALAKALAKHLAKALAKALKACEA) [23]. The arginine residues give RALA its cationic nature, enabling DNA condensation and interaction with cell membranes. Further to this, the alpha helical amphipathic structure undergoes a conformational change in the acidic endosome facilitating endosomal escape resulting in DNA transfection rates which are comparable to that of the commercially available transfection agent Lipofectamine $2000[76,88]$.

RALA has potential for a wide range of applications and has the capacity to deliver various types of nucleic acid therapeutics (and other anionic cargo) [89]. RALA was used to deliver the FK506-binding protein like - FKBPL gene ( $\mathrm{pFKBPL}$ ) - a novel member of the immunophilin protein family [90]. Overexpression of FKBPL has been shown to inhibit angiogenesis, tumour growth and stemness, through a variety of mechanisms. RALA delivered both overexpressing PFKBPL and downregulating siFKBPL in a non-toxic manner. In vivo, RALA/pFKBPL delivery retarded tumour growth, and prolonged survival with an associated decrease in angiogenesis, while RALA/siFKBPL had no effect on tumour growth rate or survival, but resulted in an increase in angiogenesis and stemness. This study demonstrates the adaptability of RALA for the delivery of both plasmid DNA and other nucleic acid therapeutics for effective gene delivery.

\subsection{Nuclear Trafficking}

Following successful endosomal escape, a gene delivery vector is released into the cytoplasm. In the case of RNAi therapeutics, this is sufficient. However, DNA requires delivery to the nucleus for transcription. Movement of macromolecules through the cytoplasm is greatly restricted due to overcrowding of organelles, the cytoskeleton of the cell and high protein concentrations which slows mobility of the vector and exposes it to the degradative action of endonucleases [91,92]. For 
successful transfection to occur, the gene delivery vector must protect the cargo and actively traffic the nucleic acid payload towards the nucleus.

\subsubsection{Trafficking towards the nucleus}

The cell cytoskeleton maintains the organelles of the cell in a functional location through the action of microtubules and motor proteins [93]. Microtubules have motor proteins, namely dyneins and kinesins, which move along the tubules in different directions and are responsible for intracellular transport of vesicles, lysosomes and endosomes [94]. It has been observed that plasmid DNA utilises microtubules, in particular dyneins, for transport towards the nucleus [95]. A number of viruses are known to exploit this host machinery to facilitate access to the nucleus [96], although little is known about the exact mechanisms and binding domains used by viruses [97]. For example, the motif sequence contained in the viral capsid hexon of the adenovirus (E3-14.7K peptide: VVMVGEKPITITQHSVETEG) promoted microtubule-mediated transport of plasmid DNA [98]. Conjugation of a plasmid encoding luciferase with E3-14.7K resulted in increased transfection efficiency up to $60 \%$ in HeLa cells, compared to $30 \%$ when conjugated to a control peptide. Incorporation of this sequence into the design of a non-viral vector may therefore improve transfection efficacy.

Acetylation of microtubules gives enhanced interactions with and trafficking of plasmid DNA. It has been observed that increasing the levels of acetylated tubulin through inhibition of the tubulin deacetylase HDAC6, results in more rapid plasmid nuclear localisation and greater levels of gene transfer. Therefore if a vector was capable of acetylating microtubules or inhibiting their deacetylation, then transfection efficiency may be improved [99]. Transcription factors, such as cyclic AMP response-element binding protein (CREB), are also implicated in the complex transport network and have been shown to be involved in facilitating movement of plasmid DNA towards and into the nucleus [100]; these transcription factor binding sites could be incorporated into plasmids to facilitate shuttling to the nucleus. Various transcription factors are implicated as having roles in 
transport of plasmids to the nucleus, and further study to elucidate the exact mechanisms could lead to more efficient DNA delivery vehicles for nuclear entry. The possibility of multiple transcription factors involved in speeding up nuclear delivery could also be important for avoiding degradation by nucleases in the cytoplasm [101].

Dynein is a multi-unit protein complex with various components capable of binding cargo. These subunits, especially the light chains such as Rp3, TcTex1 and LC8 are exploited by many viruses during infection and have been incorporated into some vectors with success [102]. A modular protein that combined TAT peptide and the dynein light chain Rp3 (T-Rp3) provoked transgene expression 7.5-fold more potently in HeLa cells than TAT alone, demonstrating the importance of microtubule transport [103]. In addition, T-Rp3 achieved transfection efficiency comparable to that of Lipofectamine, while being considerably less toxic to cells. Similarly, a recombinant fusion protein based on the dynein light chain LC8 facilitated plasmid DNA uptake into HeLa cells and transported DNA via microtubules to the nucleus for GFP transgene expression [102]. However, it is important to characterise the specificity of these binding units, since exogenous proteins may compete with vectors for binding, which could be detrimental to transfection efficiency [98].

\subsection{Nuclear envelope}

The nuclear envelope is a bilayer which protects the contents of, and tightly controls entry into the nucleus through the action of the nuclear pore complex (NPC) [104]. Passive entry into the nucleus is restricted to molecules less than $10 \mathrm{~nm}$ in diameter, which excludes the entry of DNA, and is the final barrier that needs to be overcome for successful DNA delivery.

\subsubsection{Facilitating nuclear import}

The nuclear pore tightly controls nuclear entry, but during cell division it is temporarily disassembled, and delivery of pDNA to nucleus during this period has been investigated. Symens et 
al found that coupling chromatin-targeting peptides to polystyrene beads or pDNA complexes improved inclusion in the nucleus by 2- to 3-fold when using Xenopus Nuclear Envelope Reassembly (XNER) Assay [105]. However, following microinjection in living HeLa cells, no nanoparticles were observed in the nuclei of cells post-division but accumulated in the perinuclear lysosomal compartment. Further to this, Remaut et al evaluated pDNA delivery in dividing cells using 1) phosphorylation responsive peptides that release pDNA preferentially during mitosis and 2) chromatin targeting peptides to anchor pDNA in newly formed nuclei upon cell division [106]. Each peptide was used to deliver pDNA encoding GFP in combination with a lipid-based carrier to HeLa cells. The phosphorylation peptide resulted in a slight increase in transfection efficiency of about $30 \%$; however the chromatin targeting sequence was not responsible for any improvement in transfection efficiency. Based on these studies, it seems that nuclear entry of foreign plasmid DNA is tightly controlled regardless of cell division stage and reliance on nuclear disassembly may not be as successful as first thought.

Nuclear localisation signals (NLS) are short sequences of basic amino acids that facilitate entry of cargo through the nuclear envelope, and have proved an valuable addition to vector design for gene delivery $[25,107]$. Nuclear entry facilitated by the NLSs from simian virus 40 (SV40), large tumour antigen (PKKKRKV) and Rev peptide (RRNRRRRWRERQRQ) rely particularly on arginine content $[108,109]$. A number of NLSs contain arginine-rich portions, such as TAT, Rev and Rex proteins of the retroviruses, and the tegument proteins (VP13/14) of the herpes simplex virus (HSV) type 1, which are responsible for nuclear import via the importin $\beta$ pathway [110-112]. This holds significance for vector design since the inclusion of arginines may elicit the assistance importin $\beta$ for trafficking towards the nucleus as well as entry to the nucleus [113]. However, there are some limitations to the use of NLSs, since DNA binding can be weak and covalent conjugation may hinder functionality $[107,114]$. As a result, NLSs should not be used in isolation but rather as supplements to existing vectors. For example functionalization of R8 with the SV40 NLS provoked transfection efficiency that 
was almost as effective (80\%) as jetPEI ${ }^{\mathrm{TM}}$ (transfection reagent), but lacked jetPEI ${ }^{\mathrm{TM}}{ }^{\prime} \mathrm{s}$ cytotoxicity in HeLa cells [115].

\section{Targeting}

To increase specificity for diseased tissue, and to limit off-target toxicity, targeting strategies are often employed in gene delivery vehicles. Cancer cells have unique distinguishing characteristics from normal healthy cells, which often manifests in aberrant protein and receptor expression [116]. Commonly overexpressed proteins include integrins [117], transferrin receptors [118], epidermal growth factor receptors (EGFR) [119], folate receptors [120] and proteoglycans [121]. This represents a major target for tumour-selective gene delivery, and vectors engineered with ligands can increase specificity and efficacy of therapeutics, thereby reducing side effects [122]. Furthermore, cellular uptake of gene delivery vectors may be enhanced via receptor-mediated endocytosis, and as a result much research has focused on active targeting strategies.

The advancement of phage display libraries and molecular modelling have accelerated the discovery of potential targeting peptides which are specific to cancer cells. A cell-penetrating-homing peptide (CPHP), termed RLW (RLWMRWYSPRTRAYG) was found to selectively target and penetrate A549 non-small cell lung cancer cells via an unknown mechanism [123]. RLW-functionalised PEG-PCL nanoparticles loaded with infrared dye preferentially targeted A549 over U87 xenografts. Functionalization with RLW also improved vector pharmacokinetic profile, with vector accumulation being barely detectable in organs, relative to vectors functionalised with R8 [124]. Although this strategy holds promise, the potential application is limited to use in one specific cancer and so there is a need to discover more peptides suitable for targeting various diseases. 
Yang et al used phage peptide display to identify a 5-amino acid peptide termed TMTP1 (NVVRQ), which binds to metastases [125]. They demonstrated that TMTP1 specifically bound to a series of highly metastatic tumour cells, including prostate cancer PC-3M-1E8, breast cancer MDA-MB-435S, lung cancer PG-BE1, and gastric cancer MKN-45sci, in vitro and in vivo, but not to poorly metastatic or non-metastatic cell lines. Fluorescently labelled TMTP1 administered systemically to tumourbearing mice strongly and specifically targeted micro-metastases.

TMTP1 was incorporated successfully into biopolymers and used to deliver pEGFP-N1 reporter plasmid DNA to a range of prostate cancer cells. Two of the biopolymers (RMHT and RM3GT) effectively condensed the plasmid DNA into cationic nanoparticles $<100 \mathrm{~nm}$ and were capable of transfecting PC-3 metastatic prostate cancer cells. With both RMHT and RM3GT, a higher transfection efficacy was observed in PC-3 cells than in the moderately metastatic, DU145, and normal, PNT2-C2, cell lines. Furthermore, blocking of the TMTP-1 receptors inhibited gene transfer indicating internalization via this receptor [126]. The ability to specifically target highly aggressive disseminated metastatic lesions is highly attractive for gene delivery and therefore TMTP1 has many potential applications.

\section{Multifunctional Delivery Systems}

The complex nature of systemic delivery of gene therapy requires the vector to overcome numerous barriers and challenges and ultimately requires a multifunctional system. Engineering strategies involving PEGylation and targeting ligands have potential to overcome some specific barriers but a multifunctional system must have the capacity to overcome all the barriers to gene delivery. Extensive research has focused on the design and production of such a vector with some promising prototypes being produced [127]. 


\subsection{Multifunctional envelope-type nano devices (MENDs)}

Multifunctional envelope-type nano devices (MEND) have been produced by Harashima et al through clever design and a 'programmed packaging' concept. These nanovectors comprise a core DNA-condensing cationic polymer, PLL, wrapped in a lipid envelope functionalised with various components including targeting ligands, PEG, CPPs and endosomolytic peptides [128]. Originally the MEND systems were relatively straightforward, but have evolved to a more intricate and robust delivery systems. A MEND composed of a PLL DNA-condensing core, enveloped in a lipid functionalised with stearylated R8 provoked anti-luciferase siRNA transfection that was equipotent to Lipofectamine 2000 without any detectable cytotoxicity [129]. Since then, MENDs have evolved from this non-selective system to active targeting vectors [130].

Modification of the MEND system is relatively easy and has allowed for numerous changes and functionalistions. Functionalization of R8-MEND (capable of potent transfection in HeLa cells [131]) with INF7, a pH-sensitive endosomal escape motif (derived from the HA2 protein of the influenza virus envelope) produced R8/INF7/MEND, which evoked 240- and 115-fold higher luciferase expression in mouse liver and spleen than R8-MEND, respectively [132]. This showed the potential for this delivery system to evoke strong in vivo gene expression, although expression in the liver and spleen is indicative of off-target gene expression and possible sequestration by the MPS system.

In an attempt to avoid the MPS system, a MEND was functionalised with PEG attached via a MMPcleavable linker. As described previously, PEGylation may inhibit both uptake and endosomal escape of vectors, so a cleavable linker was included to create a sheddable PEG which is cleaved in an MMPrich tumour environment. The MEND was also functionalised with $\mathrm{R} 8$ for cellular entry and the $\mathrm{pH}$ sensitive fusogenic peptide GALA for endosomal escape [133]. The PEGylated GALA/R8/MEND, used to deliver anti-luciferase siRNA, efficiently silenced luciferase expression in HT1090-luc xenografts, while an unmodified MEND showed a small silencing effect and the PEG-MEND showed no effect. 
This study highlights the importance of a step-wise, intelligent design process in the production of gene delivery systems. The MEND system has produced very promising results and with further modifications and fine-tuning, these systems have potential as successful gene delivery agents.

\subsection{Designer Biomimetic Vectors}

Despite the potential of the MEND system, their production can be quite complex with multiple conjugation steps. An exciting emerging approach is the use of recombinant DNA technology to produce bio-inspired fusion proteins, termed designer biomimetic vectors (DBVs) or designer biopolymers (DBPs), which comprise several peptide motifs, each with distinct functionality [134]. Generally, DBVs possess a DNA-condensing motif (DCM), endosomal disruption motif (EDM), nuclear localisation motif (NLS) and targeting motif (TP) $[15,135]$.

KALA-2H1-NLS-TP is a DBV that comprises two repeating units of histone H1 (2H1) for DNA condensation, KALA for pH-dependent endosome escape, a cyclic targeting peptide (TP) which targets antigens on the surface of ZR-75-1 breast cancer cells, and Rev for nuclear localisation [81]. KALA-2H1-NLS-TP preferentially targeted ZR-75-1 cells, resulting in gene transfection efficiency that was more impressive than that produced by DBV derivatives that lacked one or more functional motifs. McCarthy et al used a similar DBV for the delivery of iNOS gene therapy targeted to breast cancer and found promising therapeutic effects in vitro [136]. Another recombinant protein, tetra$\mathrm{H} 2 \mathrm{~A}(\mathrm{TH})$, that comprises four tandem repeats of human histone H2A peptide, interspersed with cathepsin D cleavage sites and GALA to facilitate the endosome escape of the cargo, was used to condense siRNA, before being coated in a cationic lipid and functionalised with PEG to give Lipidtetra-H2A-Hyaluronic acid (LHH) nanoparticles [137]. This approach has been adopted in an attempt to mimic lipid-enveloped viruses which naturally have impressive transfection abilities. Following systemic delivery of LHH nanoparticles loaded with anti-luciferase siRNA to H460-luc xenograftbearing mice, a $\sim 66 \%$ silencing of luciferase expression was observed, highlighting the potential of such vectors for in vivo applications. 
Through insightful design and optimisation, DBVs represent progress towards the production of artificial viruses for gene delivery. Recombinant DNA technology allows control of vector characteristics at the molecular level which are easily modifiable for enhancement and optimisation of functionality [138]. This promising area of research however, requires much more investigation and optimisation. To-date, only proof-of-concept evidence exists - further in vivo work with therapeutic transgenes is ultimately required to validate the concept. Table 2 summarises some of the key components and activity of MENDs and DBVs, allowing comparison of the multifunctional systems. 
Table 2: Summary of state-of-the-art MEND and DBV delivery systems.

\begin{tabular}{|c|c|c|c|c|c|c|c|}
\hline \multirow[b]{2}{*}{ Name } & \multicolumn{5}{|c|}{ Functionality } & \multirow[b]{2}{*}{$\begin{array}{c}\text { Genetic } \\
\text { material } \\
\text { delivered }\end{array}$} & \multirow[b]{2}{*}{ Activity } \\
\hline & $\begin{array}{c}\text { DNA } \\
\text { condensation }\end{array}$ & Cell entry & $\begin{array}{l}\text { Endosomal } \\
\text { escape }\end{array}$ & $\begin{array}{l}\text { Nuclear } \\
\text { entry }\end{array}$ & $\begin{array}{c}\text { Other } \\
\text { e.g. targeting } \\
\text { moiety, } \\
\text { PEGylation }\end{array}$ & & \\
\hline $\begin{array}{l}\text { R8/IN } \\
\text { F-7 } \\
\text { MEN } \\
\text { D }\end{array}$ & Protamine & $\begin{array}{l}\text { R8 } \\
\text { peptide }\end{array}$ & $\begin{array}{l}\text { INF-7 peptide } \\
\text { derived from } \\
\text { N-terminal } \\
\text { domain of } \\
\text { the HA2 } \\
\text { protein } \\
\text { influenza } \\
\text { virus } \\
\text { envelope }\end{array}$ & Protamine & - & $\begin{array}{l}\text { Plasmid } \\
\text { DNA } \\
\text { encoding } \\
\text { luciferase } \\
\text { reporter } \\
\text { gene }\end{array}$ & $\begin{array}{l}\text { Luciferase } \\
\text { transgene } \\
\text { expression levels } \\
240-\text { fold higher in } \\
\text { liver and } 115 \text {-fold } \\
\text { higher in spleen } \\
\text { than that of the } \\
\text { R8-MEND in vivo } \\
\text { [132]. }\end{array}$ \\
\hline $\begin{array}{l}\text { GALA } \\
\text { /PPD } \\
\text { MEN } \\
\text { D }\end{array}$ & $\begin{array}{l}\text { Stearylated } \\
\text { octahistidine } \\
\text { (STR-H8) }\end{array}$ & $\begin{array}{l}\text { GALA } \\
\text { peptide } \\
\text { derived } \\
\text { from HA2 }\end{array}$ & $\begin{array}{l}\mathrm{pH}- \\
\text { responsive } \\
\text { fusogenic } \\
\text { GALA peptide }\end{array}$ & $\begin{array}{l}\text { N/A } \\
\text { (siRNA } \\
\text { delivery to } \\
\text { cytosol) }\end{array}$ & $\begin{array}{l}\text { MMP- } \\
\text { cleavable PEG }\end{array}$ & $\begin{array}{l}\text { anti- } \\
\text { luciferase } \\
\text { siRNA }\end{array}$ & $\begin{array}{l}\text { Intratumoural } \\
\text { injection of } \\
\text { PPD/GALA- MEND } \\
\text { HT1080-luc into } \\
\text { human } \\
\text { fibrosarcoma } \\
\text { mouse xenografts } \\
\text { resulted in more } \\
\text { efficient luciferase } \\
\text { gene silencing } \\
\text { compared with } \\
\text { unmodified } \\
\text { MENDs in vivo } \\
\text { [133]. }\end{array}$ \\
\hline $\begin{array}{l}\text { KALA- } \\
2 \mathrm{H} 1- \\
\text { NLS- } \\
\text { TP } \\
\text { DBV }\end{array}$ & $\begin{array}{l}\text { Two } \\
\text { repeating } \\
\text { units of } \\
\text { histone } \mathrm{H} 1 \\
(2 \mathrm{H} 1)\end{array}$ & $\begin{array}{l}\text { KALA } \\
\text { peptide }\end{array}$ & $\begin{array}{l}\text { KALA peptide } \\
\text { (fusogenic) }\end{array}$ & $\begin{array}{l}\text { NLS from } \\
\text { Rev } \\
\text { protein of } \\
\text { HIV virus }\end{array}$ & $\begin{array}{l}\text { ZR-75-1 } \\
\text { targeting } \\
\text { peptide } \\
\text { (RVCFLWQDGR } \\
\text { CVF) }\end{array}$ & $\begin{array}{l}\text { Plasmid } \\
\text { DNA } \\
\text { encoding } \\
\text { luciferase } \\
\text { reporter } \\
\text { gene }\end{array}$ & $\begin{array}{l}\text { Transfection } \\
\text { efficiency of } \\
\text { luciferase } \\
\text { comparable to PEI } \\
25 \mathrm{kDa} \text { with } \\
\text { preferential } \\
\text { targeting to ZR-75- } \\
1 \text { breast cancer } \\
\text { cells [81]. }\end{array}$ \\
\hline DBV & $\begin{array}{l}\mu \text { peptide } \\
\text { derived from } \\
\text { adenovirus }\end{array}$ & $\begin{array}{l}\text { Receptor } \\
\text { mediated } \\
\text { (HER2 } \\
\text { affibody) }\end{array}$ & $\begin{array}{l}\text { H5WYG } \\
\text { histidine-rich } \\
\text { peptide, } \\
\text { derived from } \\
\text { the HA2 }\end{array}$ & $\begin{array}{l}\text { Rev } \\
\text { peptide } \\
\text { (RRNRRRR } \\
\text { WRERQRQ } \\
\text { ) derived } \\
\text { from } \\
\text { retrovirus }\end{array}$ & $\begin{array}{l}\text { HER2 affibody } \\
\text { targeting } \\
\text { moiety } \\
\text { attached via } \\
\text { cathepsin } \\
\text { substrate (CS) } \\
\text { for cleavage in } \\
\text { the endosome }\end{array}$ & $\begin{array}{l}\text { Plasmid } \\
\text { DNA } \\
\text { encoding } \\
\text { iNOS gene }\end{array}$ & $\begin{array}{l}\text { DBV-mediated } \\
\text { iNOS gene delivery } \\
\text { resulted in a } \\
\text { maximum of } 62 \% \\
\text { cell killing and less } \\
\text { than } 20 \% \\
\text { clonogenicity in } \\
\text { ZR- } 75-1 \text { breast } \\
\text { cancer cells in } \\
\text { vitro [136]. }\end{array}$ \\
\hline
\end{tabular}




\subsection{Composite delivery systems}

Some research ventures have sought an alternative to repeated parenteral delivery which is not ideal from a patient comfort and compliance standpoint. The nanoparticulate delivery systems discussed so far show great potential for overcoming barriers to gene delivery with impressive transfection efficiencies, but this may be further optimised if combined with another delivery platform to produce composite materials. Alternative delivery strategies which hold promise for gene delivery include hydrogel matrices for prolonged release depot injections and microneedles for the delivery of DNA vaccines.

\subsubsection{Hydrogel scaffolds}

Hydrogels are biocompatible scaffolds that are commonly used for localized therapy such as tissue engineering. They have desirable characteristics including a hydrated state and tissue-like environment and provide a scaffold structure that can be easily tailored. Hydrophilic polymers, which may be of natural or synthetic origin, form hydrogels through crosslinking or self-assembly. Controlled release of encapsulated materials can be achieved through optimising pore size, vectorscaffold interactions and/or degradation rate, thus making hydrogels good candidates for gene delivery depot formulations [139]. A composite system based on biodegradable folate-poly(ester amine) polymer and thermosensitive hydrogel PECE (PEG-PCL-PEG) for sustained gene release achieved transfection efficiency of $40 \%$ in C26 colon carcinoma cells, with negligible toxicity [140]. Further to this, prolonged release of DNA was observed in vitro over a seven day period from the FAPEA/DNA encapsulated PECE hydrogel, with DNA release of $18 \%(3.6 \mu \mathrm{g})$ by the end of day 3, followed by a period of slow release of $0.5 \mu \mathrm{g}$ per day. This highlights the potential of a composite hydrogel system as a prolonged release system and this approach could be especially useful for local delivery which would avoid any potential for systemic off-target effects. However, this area of research is very much in its infancy and further in vitro and in vivo work is required. Investigation of 
release profiles, toxicity, biodegradability, compatibility of vectors with hydrogel formulations and in vivo efficacy will be needed before these systems can progress further.

\subsubsection{Microneedles}

An effective alternative to parental drug delivery has been the production of transdermal delivery systems, particularly non-invasive microneedles. Microneedles have gained much attention in the pharmaceutical field since they present a novel way of overcoming the stratum corneum, a major barrier to transdermal drug delivery of a wide range of drugs and vaccines [141]. A range of microneedle formulations exist, including hollow, solid, coated, dissolvable and hydrogel forming microneedles, and microneedles are produced using a variety of materials [142].

DNA vaccination for cancer immunotherapy is one application where microneedles may improve treatment outcomes. DNA vaccines require cellular delivery of plasmid DNA to induce expression of the encoded antigen, which provokes the cytotoxic immune system to clear the antigen-presenting cells $[143,144]$. Delivery of DNA vaccines to the skin has great potential, since it is a highly immunoreactive environment containing abundant immunologically active dendritic cells that process foreign antigens and prime effective immune responses [145]. A CPP-PEI copolymer grafted with mannose (CPP-PEI1800-Man) was used to package a DNA vaccine for malignant melanoma. The DNA vaccine, comprised of a plasmid Trp2-GM-CSF-Fc-EGFP, was delivered in solution following application and removal of a solid microneedle array, and evoked adaptive T cell immune responses, important for effective immunotherapy [146]. Significantly higher levels of cytokines, including IFN- $\nu$ and IL-12 were observed in B16 melanoma xenograft-bearing BALB/c mice that were vaccinated with CPP-PEI1800-Man/pTrp2-GM-CSF-Fc-EGFP than those observed in mice treated with naked DNA. Large numbers of CD4+ and CD8+ $T$ cells were found to infiltrate the solid tumour, which can promote and amplify immune responses. This resulted in significant therapeutic anti-tumour immunity, prolonged survival time and a tumour growth inhibition of $48 \%$. In this study, the use of solid microneedles involved application of a microneedle array onto the naked abdominal skin which 
was maintained in place for $2 \mathrm{~min}$ to create microchannels in the skin. After removal of the microneedle, the nanocomplex suspension was applied to the same region. This process is not ideal however with a double application required, limited loading capability due to the transient nature of the pores formed and the need for sharps disposal following use.

For composite therapeutic gene delivery, dissolvable microneedles hold the most potential with release of the encapsulated therapeutic into the skin following application and subsequent dissolution [147]. McCaffrey et al present a novel approach where the RALA peptide is used to complex nucleic acids to form nanoparticles which are then incorporated into the polymer matrix of dissolvable microneedles [148]. It was found that the RALA/DNA nanoparticles retained their functionality following incorporation into the microneedles, and the physical strength and structure of the microneedle array was not compromised when loaded with the nanoparticles. In addition, the composite delivery platform was found to be functional both in vitro and in vivo. RALA/microneedle mediated delivery of a plasmid encoding for firefly luciferase resulted in systemic gene expression, observed in highly vascularised regions. This represents an exciting alternative strategy and highlights the potential of collaborative approaches to gene delivery and could be applied in a wide variety of applications.

\section{Future Perspective}

Cancer gene therapy has a therapeutic potential that has been unfulfilled so far, owing to the lack of a suitable delivery system. The existence of multiple extra- and intracellular barriers renders the design and engineering of a successful gene delivery vector extremely difficult, and despite the enormous amount of research ongoing in this area, the number of products gaining regulatory approval is extremely low. The development of systems such as MENDs and DBVs has shown that it is possible to create a complete multifunctional delivery vector and the possibility of creating an 
'artificial virus' may not be totally unattainable. In addition to this, the advent of composite delivery systems, such as hydrogels and microneedles, has the potential to further the advancement of gene delivery. Many of the approaches discussed here are still at an early stage of development and much pre-clinical research is yet to be carried out before further advancement will be possible. The heterogeneous nature of cancer makes it highly unlikely that a 'one size fits all' approach will be effective and each cancer necessitates a tailor-made gene therapy approach.

\section{Executive Summary}

\section{Barriers that prevent successful gene delivery}

- Extracellular barriers include packaging of nucleic acids, degradation of genetic cargo by nucleases in bodily fluids and opsonisation which triggers clearance from systemic circulation.

- Intracellular barriers include internalisation to target cells, endosomal entrapment, immobility of DNA in the cytosol and nuclear import of DNA.

\section{Strategies to overcome extracellular barriers to gene delivery}

- Stealth molecules, such as polyethylene glycol (PEG), have been used in various delivery systems to avoid clearance and prolong systemic circulation time.

- The PEG dilemma describes the problem where PEG may hinder the uptake of a vector into target cells.

- Sheddable PEG systems with cleavable linkers allow PEG to be cleaved from the delivery system at the target tumour site, allowing cellular uptake of the vector. Cleavage is usually based on tumour microenvironment conditions such as $\mathrm{pH}$ or enzymes present.

\section{Strategies to overcome intracellular barriers to gene delivery}

- Internalisation to target cells has been promoted through receptor-mediated endocytosis via attachment of specific ligands to vectors.

- Cell penetrating peptides have been very successful in enhancing cellular uptake and transfection efficiencies, especially arginine-rich peptides such as octa-arginine (R8). 
- Endosomal escape may be facilitated through inclusion of histidine-rich polymers or peptides. Alternatively, fusogenic peptides promote escape through production of pores in the endosomal membrane.

- RALA is a multifunctional peptide that can condense DNA, penetrate cell membranes and disrupt endosomes.

- In the case of DNA therapeutics, trafficking towards the nucleus and nuclear import may be enhanced with the addition of a nuclear localisation signal (NLS).

\section{Multifunctional delivery systems}

- Multifunctional envelope-type nano devices (MEND) have been produced through clever design and a 'programmed packaging' concept. They incorporate a range of functional groups including DNA condensing cores, PEG, fusogenic peptides, R8 and targeting moieties to systematically overcome all barriers to gene delivery in turn.

- Designer biomimetic vectors (DBVs) or designer biopolymers (DBPs), which comprise several peptide motifs are produced using recombinant DNA technology which allows control of vector characteristics at the molecular level.

- Generally, DBVs possess a DNA-condensing motif (DCM), endosomal disruption motif (EDM), nuclear localisation motif (NLS) and targeting motif (TP), which have been shown to successfully overcome biological barriers.

- Alternative delivery strategies which hold promise for gene delivery include composite delivery platforms, such as hydrogel matrices for prolonged release depot injections, and microneedles for the delivery of DNA vaccines via the skin.

\section{References}

1. Brenner MK, Gottschalk S, Leen AM, Vera JF. Is cancer gene therapy an empty suit? Lancet Oncol. 14(11), e447-e456 (2013)

2. Wysocki PJ, Mackiewicz-Wysocka M, Mackiewicz A. Cancer gene therapy - state-of-the-art. Reports 
Pract. Oncol. Radiother. 7(4), 149-155 (2002).

3. Liu J, Zhang C, Feng Z. Tumor suppressor p53 and its gain-of-function mutants in cancer. Acta Biochim. Biophys. 46(3), 170-179 (2014).

4. Ternovoi V V, Curiel DT, Smith BF, Siegal GP. Adenovirus-mediated p53 tumor suppressor gene therapy of osteosarcoma. Lab. Invest. 86, 748-766 (2006).

5. Senzer N, Nemunaitis J, Nemunaitis D, et al. Phase I study of a systemically delivered p53 nanoparticle in advanced solid tumors. Mol. Ther. 21(5), 1096-103 (2013).

6. The Journal of Gene Medicine. Indications Addressed by Gene Therapy Clinical Trials [Internet]. (2016). Available from: http://www.abedia.com/wiley/indications.php.

7. Wirth T, Parker N, Ylä-Herttuala S. History of gene therapy. Gene. 525(2), 162-169 (2013).

8. Morille M, Passirani C, Vonarbourg A, Clavreul A, Benoit J-P. Progress in developing cationic vectors for non-viral systemic gene therapy against cancer. Biomaterials. 29(24-25), 3477-96 (2008).

9. Templeton NS. Cationic liposome-mediated gene delivery in vivo. Biosci. Rep. 22(2), 283-295 (2002).

10. Wilson JM. Lessons learned from the gene therapy trial for ornithine transcarbamylase deficiency. Mol. Genet. Metab. 96(4), 151-157 (2009).

11. Ginn SL, Alexander IE, Edelstein ML, Abedi MR, Wixon J. Gene therapy clinical trials worldwide to 2012 - an update. J. Gene Med. 15(2), 65-77 (2013).

12. The Journal of Gene Medicine. Vectors used in Gene Therapy Clinical Trials [Internet]. (2016). Available from: http://www.abedia.com/wiley/vectors.php.

13. Tros de Ilarduya C, Sun Y, Düzgüneş N. Gene delivery by lipoplexes and polyplexes. Eur. J. Pharm. Sci. 40, 159-170 (2010).

14. Wang T, Upponi JR, Torchilin VP. Design of multifunctional non-viral gene vectors to overcome physiological barriers: dilemmas and strategies. Int. J. Pharm. 427(1), 3-20 (2012).

15. Hatefi A, Megeed Z, Ghandehari H. Recombinant polymer-protein fusion: a promising approach towards efficient and targeted gene delivery. J. Gene Med. 8(4), 468-76 (2006).

16. De Laporte L, Cruz Rea J, Shea LD. Design of modular non-viral gene therapy vectors. Biomaterials. 27(7), 947-54 (2006).

17. Saccardo P, Villaverde A, González-Montalbán N. Peptide-mediated DNA condensation for non-viral gene therapy. Biotechnol. Adv. 27(4), 432-8 (2009). 
18. Blanco E, Shen H, Ferrari M. Principles of nanoparticle design for overcoming biological barriers to drug delivery. Nat. Biotechnol. 33(9), 941-951 (2015).

19. Owens DE, Peppas NA. Opsonization, biodistribution, and pharmacokinetics of polymeric nanoparticles. Int. J. Pharm. 307, 93-102 (2006).

20. Wang M, Thanou M. Targeting nanoparticles to cancer. Pharmacol. Res. 62(2), 90-9 (2010).

21. Ziello JE, Huang Y, Jovin IS. Cellular endocytosis and gene delivery. Mol. Med. 16(5-6), 222-9 (2010).

22. Howes MT, Mayor S, Parton RG. Molecules, mechanisms, and cellular roles of clathrin-independent endocytosis. Curr. Opin. Cell Biol. 22(4), 519-527 (2010).

23. Varkouhi AK, Scholte M, Storm G, Haisma HJ. Endosomal escape pathways for delivery of biologicals. J. Control. Release. 151(3), 220-8 (2011).

24. Döhner K, Nagel C-H, Sodeik B. Viral stop-and-go along microtubules: taking a ride with dynein and kinesins. Trends Microbiol. 13(7), 320-7 (2005).

25. Dean DA, Strong DD, Zimmer WE. Nuclear entry of nonviral vectors. Gene Ther. 12(11), 881-90 (2005).

26. Ogris M, Brunner S, Schüller S, Kircheis R, Wagner E. PEGylated DNA/transferrin-PEI complexes: reduced interaction with blood components, extended circulation in blood and potential for systemic gene delivery. Gene Ther. 6(October 1998), 595-605 (1999).

27. Moghimi SM, Hunter AC, Murray JC. Long-Circulating and Target-Specific Nanoparticles : Theory to Practice. 53(2), 283-318 (2001).

28. Moghimi SM, Andersen AJ, Hashemi SH, et al. Complement activation cascade triggered by PEG-PL engineered nanomedicines and carbon nanotubes: The challenges ahead. J. Control. Release. 146(2), 175-181 (2010).

29. Johnson R. The complement system. In: Biomaterials Science: An Introduction to Materials in Medicine. Ratner BD, Hoffman AS, Schoen FJ, Lemons JE (Eds). Elsevier Academic Press, Amsterdam, 318-328 (2004).

30. Janeway Jr CA, Travers P, Walport M, Shlomchik MJ. The complement system and innate immunity. In: Immunobiology: The Immune System in Health and Disease. Garland Science New York (2001).

31. Bilzer M, Roggel F, Gerbes AL. Role of Kupffer cells in host defense and liver disease. Liver Int. 26(10), 1175-1186 (2006).

32. Moghimi SM, Hunter a C, Murray JC. Nanomedicine: current status and future prospects. FASEB J. 19, 
311-330 (2005).

33. Veronese FM, Pasut G. PEGylation, successful approach to drug delivery. Drug Discov. Today. 10(21), 1451-1458 (2005).

34. Li Z, Qiu L, Chen Q, et al. pH-sensitive nanoparticles of poly(I-histidine)-poly(lactide-co-glycolide)tocopheryl polyethylene glycol succinate for anti-tumor drug delivery. Acta Biomater. 11, 137-150 (2015).

35. Bertrand N, Wu J, Xu X, Kamaly N, Farokhzad OC. Cancer nanotechnology: The impact of passive and active targeting in the era of modern cancer biology. Adv. Drug Deliv. Rev. 66, 2-25 (2014).

36. Khawar IA, Kim JH, Kuh H-J. Improving drug delivery to solid tumors: Priming the tumor microenvironment. J. Control. Release. 201, 78-89 (2015).

37. Mcdonald DM, Baluk P. Significance of Blood Vessel Leakiness in Cancer. Cancer Res. 62, 5381-5385 (2002).

38. Hayes DF, Paoletti C. Circulating tumour cells: Insights into tumour heterogeneity. J. Intern. Med. 274(2), 137-143 (2013).

39. Hatakeyama $\mathrm{H}$, Akita $\mathrm{H}$, Harashima $\mathrm{H}$. The polyethyleneglycol dilemma: advantage and disadvantage of PEGylation of liposomes for systemic genes and nucleic acids delivery to tumors. Biol. Pharm. Bull. 36(6), 892-9 (2013).

*40. Romberg B, Hennink WE, Storm G. Sheddable coatings for long-circulating nanoparticles. Pharm. Res. 25(1), 55-71 (2008).

* Great article highlighting the application of various PEGylation strategies to improve therapeutic delivery in vivo.

41. Pasut G, Veronese FM. State of the art in PEGylation: The great versatility achieved after forty years of research. J. Control. Release. 161(2), 461-472 (2012).

42. Kato Y, Ozawa S, Miyamoto C, et al. Acidic extracellular microenvironment and cancer. Cancer Cell Int. 13(1), 89 (2013).

43. Lee ES, Na K, You Han B. Polymeric micelle for tumor pH and folate-mediated targeting. J. Control. Release. 91(1-2), 103-113 (2003).

44. Huang D, Li C, Zhang H. Hypoxia and cancer cell metabolism. Acta Biochim. Biophys. 46(January), 214219 (2014). 
45. Fella C, Walker GF, Ogris M, Wagner E. Amine-reactive pyridylhydrazone-based PEG reagents for $\mathrm{pH}-$ reversible PEI polyplex shielding. Eur. J. Pharm. Sci. 34(4-5), 309-20 (2008).

*46. Zhang X-X, Eden HS, Chen X. Peptides in cancer nanomedicine: drug carriers, targeting ligands and protease substrates. J. Control. Release. 159(1), 2-13 (2012).

*Article highlight the various potential applications which peptides may have in cancer gene delivery

47. Yadav L, Puri N, Rastogi V, Satpute P, Ahmad R, Kaur G. Matrix metalloproteinases and cancer - roles in threat and therapy. Asian Pac. J. Cancer Prev. 15(3), 1085-91 (2014).

48. Li H, Yu SS, Miteva M, et al. Matrix Metalloproteinase Responsive, proximity-activated polymeric nanoparticles for siRNA delivery. Adv Funct Mater. 23(24), 3040-3052 (2013).

49. Liu Y, Zhang D, Qiao ZY, et al. A Peptide-Network Weaved Nanoplatform with Tumor Microenvironment Responsiveness and Deep Tissue Penetration Capability for Cancer Therapy. Adv. Mater. 27(34), 5034-5042 (2015).

50. D'Souza SE, Ginsberg MH, Plow EF. Arginyl-glycyl-aspartic acid (RGD): a cell adhesion motif. Trends Biochem. Sci. 16(7), 246-50 (1991).

51. Seguin L, Desgrosellier JS, Weis SM, Cheresh DA. Integrins and cancer: regulators of cancer stemness, metastasis, and drug resistance. Trends Cell Biol. , 1-7 (2015).

52. Park J, Singha K, Son S, et al. A review of RGD-functionalized nonviral gene delivery vectors for cancer therapy. Cancer Gene Ther. 19(11), 741-748 (2012).

53. Godbey WT, Mikos a G. Recent progress in gene delivery using non-viral transfer complexes. J. Control. Release. 72, 115-125 (2001).

54. Brooks H, Lebleu B, Vivès E. Tat peptide-mediated cellular delivery: back to basics. Adv. Drug Deliv. Rev. 57(4), 559-77 (2005).

55. El-Sayed A, Harashima H. Endocytosis of gene delivery vectors: from clathrin-dependent to lipid raftmediated endocytosis. Mol. Ther. 21(6), 1118-30 (2013).

56. Rewatkar P V., Parton RG, Parekh HS, Parat M-O. Are caveolae a cellular entry route for non-viral therapeutic delivery systems? Adv. Drug Deliv. Rev. 91, 92-108 (2015).

57. Kerr MC, Teasdale RD. Defining macropinocytosis. Traffic. 10(2), 364-371 (2009).

58. Brock R. The uptake of arginine-rich cell-penetrating peptides: putting the puzzle together. Bioconjug. Chem. 25(5), 863-8 (2014). 
59. Moghimi SM, Symonds P, Murray JC, Hunter a. C, Debska G, Szewczyk A. A two-stage poly(ethylenimine)-mediated cytotoxicity: Implications for gene transfer/therapy. Mol. Ther. 11(6), 990-995 (2005).

60. Han K, Yang J, Chen S, et al. Novel gene transfer vectors based on artificial recombinant multifunctional oligopeptides. Int. J. Pharm. 436(1-2), 555-63 (2012).

61. Loughran SP, McCrudden CM, McCarthy HO. Designer peptide delivery systems for gene therapy. Eur. J. Nanomedicine. 7(2), 85-96 (2015).

62. Li J, Fan C, Pei H, Shi J, Huang Q. Smart drug delivery nanocarriers with self-assembled DNA nanostructures. Adv. Mater. 25(32), 4386-4396 (2013).

63. Lee H, Lytton-Jean AKR, Chen Y, et al. Molecularly self-assembled nucleic acid nanoparticles for targeted in vivo siRNA delivery. Nat. Nanotechnol. 7(6), 389-393 (2012).

64. Heitz F, Morris MC, Divita G. Twenty years of cell-penetrating peptides : from molecular mechanisms to therapeutics. (October 2008), 195-206 (2009).

65. Deshayes S, Morris MC, Divita G, Heitz F. Cell-penetrating peptides: tools for intracellular delivery of therapeutics. Cell. Mol. Life Sci. 62(16), 1839-49 (2005).

66. Vives E, Brodin P, Lebleu B. A Truncated HIV-1 Tat Protein Basic Domain Rapidly Translocates through the Plasma Membrane and Accumulates in the Cell Nucleus. J. Biol. Chem. 272(25), 16010-16017 (1997).

67. Mann A, Thakur G, Shukla V, Ganguli M. Peptides in DNA delivery: current insights and future directions. Drug Discov. Today. 13(3-4), 152-60 (2008).

68. Schmidt N, Mishra A, Lai GH, Wong GCL. Arginine-rich cell-penetrating peptides. FEBS Lett. 584(9), 1806-13 (2010).

69. Derossi D, Joliot A, Chassaing G, Prochiantztn A. The third helix of the Antennapedia homeodomain translocates through biological membranes. J. Biol. Chem. , 10444-10450 (1994).

70. Scheller A, Oehlke J, Wiesner B, et al. Structural requirements for cellular uptake of alpha-helical amphipathic peptides. J. Pept. Sci. 5, 185-194 (1999).

71. Bolhassani A. Potential efficacy of cell-penetrating peptides for nucleic acid and drug delivery in cancer. Biochim. Biophys. Acta. 1816(2), 232-46 (2011).

72. Gonçalves E, Kitas E, Seelig J. Binding of oligoarginine to membrane lipids and heparan sulfate: 
structural and thermodynamic characterization of a cell-penetrating peptide. Biochemistry. , 26922702 (2005).

73. Mitchell DJ, Kim DT, Steinman L, Fathman CG, Rothbard JB. Polyarginine enters cells more efficiently than other polycationic homopolymers. J. Pept. Res. 56, 318-325 (2000).

74. Chang M, Huang Y-W, Aronstam R, Lee H-J. Cellular Delivery of Noncovalently-Associated Macromolecules by Cell- Penetrating Peptides. Curr. Pharm. Biotechnol. 15(3), 267-275 (2014).

75. Nakase I, Takeuchi T, Tanaka G, Futaki S. Methodological and cellular aspects that govern the internalization mechanisms of arginine-rich cell-penetrating peptides. Adv. Drug Deliv. Rev. 60(4-5), 598-607 (2008).

76. Futaki S, Nakase I, Tadokoro A, Takeuchi T, Jones a T. Arginine-rich peptides and their internalization mechanisms. Biochem. Soc. Trans. 35(Pt 4), 784-7 (2007).

77. Jiang QY, Lai LH, Shen J, Wang QQ, Xu FJ, Tang GP. Gene delivery to tumor cells by cationic polymeric nanovectors coupled to folic acid and the cell-penetrating peptide octaarginine. Biomaterials. 32(29), 7253-7262 (2011).

78. Verdurmen WPR, Bovee-Geurts PH, Wadhwani P, et al. Preferential uptake of L-versus D-amino acid cell-penetrating peptides in a cell type-dependent manner. Chem. Biol. 18, 1000-1010 (2011).

79. Melikov K, Chernomordik L V. Arginine-rich cell penetrating peptides: from endosomal uptake to nuclear delivery. Cell. Mol. Life Sci. 62(23), 2739-49 (2005).

80. Billiet L, Gomez JP, Berchel M, et al. Gene transfer by chemical vectors, and endocytosis routes of polyplexes, lipoplexes and lipopolyplexes in a myoblast cell line. Biomaterials. 33(10), 2980-2990 (2012).

81. Soltani F, Sankian M, Hatefi A, Ramezani M. Development of a novel histone H1-based recombinant fusion peptide for targeted non-viral gene delivery. Int. J. Pharm. 441(1-2), 307-15 (2013).

82. Cho YW, Kim J-D, Park K. Polycation gene delivery systems: escape from endosomes to cytosol. J. Pharm. Pharmacol. 55(6), 721-34 (2003).

83. Midoux P, Kichler A, Boutin V, Maurizot JC, Monsigny M. Membrane permeabilization and efficient gene transfer by a peptide containing several histidines. Bioconjug. Chem. 9(2), 260-7 (1998).

84. Asseline U, Gonçalves C, Pichon C, Midoux P. Improved nuclear delivery of antisense 2'-Ome RNA by conjugation with the histidine-rich peptide H5WYG. J. Gene Med. 16(7-8), 157-65. 
85. Lo SL, Wang S. An endosomolytic Tat peptide produced by incorporation of histidine and cysteine residues as a nonviral vector for DNA transfection. Biomaterials. 29(15), 2408-14 (2008).

86. Hafez IM, Cullis PR. Roles of lipid polymorphism in intracellular delivery. Adv. Drug Deliv. Rev. 47, 139148 (2001).

87. Liou JS, Liu BR, Martin AL, Huang YW, Chiang HJ, Lee HJ. Protein transduction in human cells is enhanced by cell-penetrating peptides fused with an endosomolytic HA2 sequence. Peptides. 37(2), 273-284 (2012).

*88. McCarthy HO, McCaffrey J, McCrudden CM, et al. Development and characterization of self-assembling nanoparticles using a bio-inspired amphipathic peptide for gene delivery. J. Control. Release. 189, 1419 (2014).

* Excellent example of how rational vector design can be used to enhance the properites of a delivery system resulting in improved gene delivery.

89. Massey AS, Pentlavalli S, Cunningham R, et al. Potentiating the Anticancer Properties of Bisphosphonates by Nanocomplexation with the Cationic Amphipathic Peptide, RALA. Mol. Pharm. 13(4), 1217-28 (2016).

90. Bennett $\mathrm{R}$, Yakkundi A, McKeen $\mathrm{H}$, et al. RALA-mediated delivery of FKBPL nucleic acid therapeutics. Nanomedicine. 10(19), 2989-3001 (2015).

91. Zhang X-X, Mclntosh TJ, Grinstaff MW. Functional lipids and lipoplexes for improved gene delivery. Biochimie. 94(1), 42-58 (2012).

92. Moseley GW, Leyton DL, Glover DJ, Filmer RP, Jans D a. Enhancement of protein transductionmediated nuclear delivery by interaction with dynein/microtubules. J. Biotechnol. 145(3), 222-5 (2010).

93. Alieva IB. Role of microtubule cytoskeleton in regulation of endothelial barrier function. Biochem. 79(9), 964-75 (2014).

94. Vale RD. The molecular motor toolbox for intracellular transport. 112, 467-480 (2003).

95. Vaughan EE, Dean DA. Intracellular trafficking of plasmids during transfection is mediated by microtubules. Mol. Ther. 13(2), 422-428 (2006).

96. Zhang W, Greene W, Gao S-J. Microtubule- and dynein-dependent nuclear trafficking of rhesus rhadinovirus in rhesus fibroblasts. J. Virol. 86(1), 599-604 (2012). 
97. Hsieh MJ, White PJ, Pouton CW. Interaction of viruses with host cell molecular motors. Curr. Opin. Biotechnol. 21(5), 633-9 (2010).

98. Pigeon L, Gonçalves C, Gosset D, Pichon C, Midoux P. An E3-14.7K peptide that promotes microtubulesmediated transport of plasmid DNA increases polyplexes transfection efficiency. Small. 9(22), 3845-51 (2013).

99. Badding MA, Dean DA. Highly acetylated tubulin permits enhanced interactions with and trafficking of plasmids along microtubules. Gene Ther. 20(6), 616-24 (2013).

100. Badding MA, Vaughan EE, Dean DA. Transcription factor plasmid binding modulates microtubule interactions and intracellular trafficking during gene transfer. Gene Ther. 19(3), 338-46 (2012).

101. Lechardeur D, Sohn KJ, Haardt M, et al. Metabolic instability of plasmid DNA in the cytosol: a potential barrier to gene transfer. Gene Ther. 6(4), 482-97 (1999).

102. Toledo M a S, Janissen R, Favaro MTP, et al. Development of a recombinant fusion protein based on the dynein light chain LC8 for non-viral gene delivery. J. Control. Release. 159(2), 222-31 (2012).

103. Favaro MTP, de Toledo M a S, Alves RF, et al. Development of a non-viral gene delivery vector based on the dynein light chain Rp3 and the TAT peptide. J. Biotechnol. 173, 10-8 (2014).

104. Hébert E. Improvement of exogenous DNA nuclear importation by nuclear localization signal-bearing vectors: a promising way for non-viral gene therapy. Biol. Cell. 95(2), 59-68 (2003).

105. Symens N, Walzack R, Demeester J, Mattaj I, De Smedt SC, Remaut K. Nuclear inclusion of inert and chromatin-targeted polystyrene spheres and plasmid DNA containing nanoparticles. Mol. Pharm. 8, 1757-1766 (2011).

106. Remaut K, Symens N, Lucas B, Demeester J, De Smedt SC. Cell division responsive peptides for optimized plasmid DNA delivery: The mitotic window of opportunity? J. Control. Release. 179(1), 1-9 (2014).

107. Escriou V, Carrière M, Scherman D, Wils P. NLS bioconjugates for targeting therapeutic genes to the nucleus. Adv. Drug Deliv. Rev. 55, 295-306 (2003).

108. Kalderon D, Roberts B, Richardson W, Smith A. A short amino acid sequence able to specify nuclear localisation. Cell. 39, 499-509 (1984).

109. Elder RM, Jayaraman A. Molecular simulations of polycation-DNA binding exploring the effect of peptide chemistry and sequence in nuclear localization sequence based polycations. J. Phys. Chem. B. 
(2013).

110. Donnelly M, Elliott G. Nuclear localization and shuttling of herpes simplex virus tegument protein VP13/14. J. Virol. 75(6), 2566-74 (2001).

111. Pollard VW, Malim MH. THE HIV-1 Rev Protein: Overview of the Retroviral Life Cycle. Annu. Rev. Microbiol. , 491-532 (1998).

112. Palmeri D, Malim MH. Importin beta can mediate the nuclear import of an arginine-rich nuclear localization signal in the absence of importin alpha. Mol. Cell. Biol. 19(2), 1218-1225 (1999).

113. Van der Aa MAEM, Mastrobattista E, Oosting RS, Hennink WE, Koning GA, Crommelin DJA. The Nuclear Pore Complex: The Gateway to Successful Nonviral Gene Delivery. Pharm. Res. 23(3), 447-459 (2006).

114. Ludtke JJ, Zhang G, Sebestyén MG, Wolff JA. A nuclear localization signal can enhance both the nuclear transport and expression of 1 kb DNA. J. Cell Sci. 112 (Pt 12, 2033-41 (1999).

115. Wang H-Y, Chen J-X, Sun $\mathrm{Y}-\mathrm{X}$, et al. Construction of cell penetrating peptide vectors with $\mathrm{N}$-terminal stearylated nuclear localization signal for targeted delivery of DNA into the cell nuclei. J. Control. Release. 155(1), 26-33 (2011).

116. Torchilin VP, Lukyanov AN. Peptide and protein drug delivery to and into tumors: challenges and solutions. Drug Discov. Today. 8(6), 259-266 (2003).

117. Goodman SL, Picard M. Integrins as therapeutic targets. Trends Pharmacol. Sci. 33(7), 405-412 (2012).

118. Daniels TR, Bernabeu E, Rodríguez J a., et al. The transferrin receptor and the targeted delivery of therapeutic agents against cancer. Biochim. Biophys. Acta - Gen. Subj. 1820(3), 291-317 (2012).

119. Mendelsohn J. The epidermal growth factor receptor as a target for cancer therapy. Endocr. Relat. Cancer. 8(1), 3-9 (2001).

120. Lu Y, Low PS. Folate-mediated delivery of macromolecular anticancer therapeutic agents. Adv. Drug Deliv. Rev. 54(5), 675-93 (2002).

121. Iozzo RV, Sanderson RD. Proteoglycans in cancer biology, tumor microenvironment and angiogenesis. J Cell Mol Med. 15(5), 1013-1031 (2011).

122. Curnis F, Gasparri A, Sacchi A, Longhi R, Corti A. Coupling tumor necrosis factor- $\alpha$ with $\alpha$ V integrin ligands improves its antineoplastic activity. Cancer Res. 64, 565-571 (2004).

123. Kondo E, Saito K, Tashiro Y, et al. Tumour lineage-homing cell-penetrating peptides as anticancer molecular delivery systems. Nat. Commun. 3, 951 (2012). 
124. Gao H, Zhang Q, Yang Y, Jiang X, He Q. Tumor homing cell penetrating peptide decorated nanoparticles used for enhancing tumor targeting delivery and therapy. Int. J. Pharm. 478(1), 240-250 (2015).

125. Yang W, Luo D, Wang S, et al. TMTP1, a novel tumor-homing peptide specifically targeting metastasis. Clin. Cancer Res. 14(17), 5494-5502 (2008).

126. McBride JW, Massey AS, McCaffrey J, et al. Development of TMTP-1 targeted designer biopolymers for gene delivery to prostate cancer. Int. J. Pharm. 500(1-2), 144-153 (2016).

127. McErlean EM, McCrudden CM, McCarthy HO. Multifunctional Delivery Systems for Cancer Gene Therapy. In: Gene Therapy: Principles and Challenges. Doaa Hashad (Ed). InTech, 57-104 (2015).

128. Kogure K, Akita H, Harashima H. Multifunctional envelope-type nano device for non-viral gene delivery: Concept and application of Programmed Packaging. J. Control. Release. 122, 246-251 (2007).

129. Moriguchi R, Kogure $\mathrm{K}$, Akita $\mathrm{H}$, et al. A multifunctional envelope-type nano device for novel gene delivery of siRNA plasmids. Int. J. Pharm. 301, 277-285 (2005).

*130. Hayashi Y, Hatakeyama H, Kajimoto K, Hyodo M, Akita H, Harashima H. Multifunctional Envelope-Type Nano Device: Evolution from Nonselective to Active Targeting System. Bioconjug. Chem. 26(7), 12661276 (2015).

*This article highlights the development of the MEND system and the importance of targeting.

131. Nakamura Y, Kogure K, Futaki S, Harashima H. Octaarginine-modified multifunctional envelope-type nano device for siRNA. J. Control. Release. 119, 360-367 (2007).

132. El-Sayed A, Masuda T, Khalil I, Akita H, Harashima H. Enhanced gene expression by a novel stearylated INF7 peptide derivative through fusion independent endosomal escape. J. Control. Release. 138(2), 160-167 (2009).

133. Hatakeyama $\mathrm{H}$, Ito $\mathrm{E}$, Akita $\mathrm{H}$, et al. A pH-sensitive fusogenic peptide facilitates endosomal escape and greatly enhances the gene silencing of siRNA-containing nanoparticles in vitro and in vivo. J. Control. Release. 139(2), 127-32 (2009).

134. Sadeghian F, Hosseinkhani S, Alizadeh A, Hatefi A. Design, engineering and preparation of a multidomain fusion vector for gene delivery. Int. J. Pharm. 427(2), 393-9 (2012).

135. Wang Y, Mangipudi SS, Canine BF, Hatefi A. A designer biomimetic vector with a chimeric architecture for targeted gene transfer. J. Control. Release. 137(1), 46-53 (2009).

136. McCarthy HO, Zholobenko A V, Wang Y, et al. Evaluation of a multi-functional nanocarrier for targeted 
breast cancer iNOS gene therapy. Int. J. Pharm. 405(1-2), 196-202 (2011).

137. Wang Y, Zhang L, Guo S, Hatefi A, Huang L. Incorporation of histone derived recombinant protein for enhanced disassembly of core-membrane structured liposomal nanoparticles for efficient siRNA delivery. J. Control. Release. 172, 179-189 (2013).

*138. McCarthy HO, Wang, Yuhua, Mangipudi S, Hatefi A. Advances with the use of bio-inspired vectors towards creation of artifical viruses. Expert Opin. Drug Deliv. 7(4), 497-512 (2010).

* Excellent review article detailing how inspiration for gene delivery vectors can be taken from viruses which have naturally evolved over time to transfect host cells.

139. Germershaus O, Nultsch K. Localized, non-viral delivery of nucleic acids: Opportunities, challenges and current strategies. Asian J. Pharm. Sci. 10(3), 159-175 (2015).

140. Yang Y, Zhao H, Jia Y, et al. A novel gene delivery composite system based on biodegradable folate-poly (ester amine) polymer and thermosensitive hydrogel for sustained gene release. Sci. Rep. 6(October 2015), 21402 (2016).

141. Larrañeta E, McCrudden MTC, Courtenay AJ, Donnelly RF. Microneedles: A New Frontier in Nanomedicine Delivery. Pharm. Res. 33(5), 1055-1073 (2016).

142. Ita K. Transdermal delivery of drugs with microneedles - potential and challenges. Pharmaceutics. 7(3), 90-105 (2015).

143. Suckow MA. Cancer vaccines: harnessing the potential of anti-tumor immunity. Vet. J. 198(2013), 2833 (2013).

144. Cole G, McCaffrey J, Ali AA, McCarthy HO. DNA vaccination for prostate cancer: key concepts and considerations. Cancer Nanotechnol. 6(1), 2 (2015).

145. Ono S, Kabashima K. Novel insights into the role of immune cells in skin and inducible skin-associated lymphoid tissue (iSALT). Allergo J. Int. 24(6), 170-179 (2015).

*146. Hu Y, Xu B, Xu J, et al. Microneedle-assisted dendritic cell-targeted nanoparticles for transcutaneous DNA immunization. Polym. Chem. 6(3), 373-379 (2015).

* Example of a composite delivery system combining microneedle technology with a DNA vaccine to produce a successful therapeutic effect.

147. McCaffrey J, Donnelly RF, McCarthy HO. Microneedles: an innovative platform for gene delivery. Drug Deliv. Transl. Res. 5(4), 424-37 (2015). 
148. McCaffrey J, McCrudden CM, Ali AA, et al. Transcending epithelial and intracellular biological barriers; A prototype DNA delivery device. J. Control. Release. 226, 238-247 (2016).

\section{Conflict of Interest}

The authors declare no conflict of interest in this manuscript. 